\title{
The Potential of Chocolate Products as a Culinary Business (A Study in Tangerang, Banten)
}

\author{
Jesica Laurencia Putri ${ }^{1}$, Diena Mutiara Lemy ${ }^{2}$ \\ ${ }^{1,2}$ Pelita Harapan School of Hospitality and Tourism, Jakarta, Indonesia \\ Jesicalaurencia22@yahoo.com, diena.lemy@uph.edu
}

\begin{abstract}
Tourism sector has a good impact for the destination's local economy. Restaurant is a part of toursim sector. Types of restaurant are grouped based on the product and service given for the customer. Dessert can not be seperated from the existence of restaurant. One of the dessert product found in some dessert cafe is chocolate product. The potential of restaurant is also giving some benefit for the capital owner who develops the culinary business. Therefore, chocolate product which is one of the dessert product, should has a power for developing the culinary business. By doing a research based on related sources and response from respondent through questionnaire, the data result from those sources will be used to show the chocolate product potential in the culinary business. The potential of chocolate product is needed and giving an affect for the capital owner who is going to run a dessert cafe business.
\end{abstract}

Keywords-Tourim, Restaurant, Chocolate, Culinary, Potential.

\section{INTRODUCTION}

Tourism is defined as an activity done by a person who travels from one place to another place outside the neighborhood environment for no more than one year for some purpose such as leisure, business and another purpose that not related with the paid activities from the visited place (Ana et.al., 2015). Tourism is classified into some components that giving its own contribution for the local economy and also affecting the level of customer satisfaction. The tourism components are accomodation, transportation, hotel, restaurant, facilities, activities and others. Tourism sector also plays a role directly on the society and workers welfare in Indonesia.

TABLE I. ANNUAL GDP DISTRIBUTION AT CURRENT PRICES (PERCENT)

\begin{tabular}{lccc}
\hline \multirow{2}{*}{ GDP on Business Field } & \multicolumn{3}{c}{ Year } \\
\cline { 2 - 4 } & 2014 & 2015 & 2016 \\
\hline Provision of Accommodation and Food & 3,04 & 2,96 & 2,92 \\
Beverage & 0,70 & 0,70 & 0,69 \\
1. Provision of Accommodation & 2,34 & 2,26 & 2,23 \\
2. Provision of Food Beverage & & &
\end{tabular}

Source: Statistic Indonesia (2016)

Tabel I shows the annual GDP distribution which is classified into provision of accommodation and provision of food beverage. It shows that provision of food beverage is higher than the provision of accommodation, so in other words, the amount of food and beverage provider is greater than the accommodation provider. People enjoy the food and beverage at restaurant. Restaurant is a commercial business that providing food and beverage for public (Beckett,S.T., 2009).

One of the Indonesia's variety of restaurant is bakery. Based on the growth data of food services outlet in Indonesia, the percentage of bakery products is having an increase of 2,6\% on 2014 and this growth is estimated will reaching 2,3\% on 2015 until 2019 (Page,S.J., 2015). Besides bakery products, patisserie also has an important role on supporting the success of restaurant and another food service outlets, and the existence of patisserie business is increasing, especially in Indonesia. The patisserie business has been developed at the baking techniques, form of products, decoration, delivery, and packaging (Rangkuti et.al., 2015). Each patisserie product has some ingredients to create the core product. The characteristic of patisserie business is different with the other culinary techniques, because it needs a special attention when choosing the right ingredients, right 
measurement of each ingredients used, and right baking method (Rangkuti et.al., 2015). The ingredients will affect the resulf of the products. Some of the ingredients of patisserie products also known as dairy products. Ingredients that usually used are sugar, flour, honey, ream, butter, milk, eggs, chocolate, chocolate powder, baking powder, baking soda, and others.

Tourism sector also plays a role directly on the society and workers welfare in Indonesia. Based on data from World Travel \& Tourism Council (2017), tourism sector has given 108.741.000 jobs on 2016 and taking a part for 3,6\% of the total job. Based on that statement, it means there are a lot of jobs created by this sector. One of the jobs created is restaurant. The Indonesian Hotel, Restaurant, and Institutional (HRI) Sector is diverse, and it is including the luxury hotel and restaurant that serving local and international food, fast food outlets, cafe and bar, bakery and middle-low restaurant (Page, S.J., 2015). One of types of cafe that has been developed is cafe with chocolate product, the current one that will be investigated from the side of its potential in the culinary business. The crowd of restaurant business that will be run, also creating an attention for the potential of the business in Tangerang, and one of the business is the cafe with chocolate products on it.

TABLE II. POPULATION AND POPULATION GROWTH RATE BY REGENCY / CITY IN BANTEN PROVINCE

\begin{tabular}{|c|c|c|c|}
\hline \multirow{3}{*}{ Regency / City } & \multicolumn{3}{|c|}{ Year } \\
\hline & 2014 & 2015 & 2016 \\
\hline & \multicolumn{2}{|c|}{ Regency } & \\
\hline Pandeglang & 1.154 .207 & 1.194 .911 & 1.200 .512 \\
\hline Lebak & 1.209 .207 & 1.269 .812 & 1.279 .412 \\
\hline Tangerang & 2.852 .182 & 3.370 .594 & 3.477 .495 \\
\hline \multirow[t]{2}{*}{ Serang } & 1.408 .796 & 1.474 .301 & 1.484 .502 \\
\hline & \multicolumn{2}{|c|}{ City } & \\
\hline Tangerang & 1.808 .498 & 2.047 .105 & 2.093 .706 \\
\hline Cilegon & 376.404 & 412.106 & 418.705 \\
\hline Serang & 580.802 & 643.205 & 655.004 \\
\hline Tangerang Selatan & 1.298 .504 & 1.543 .209 & 1.593 .812 \\
\hline
\end{tabular}

Source: Indonesian Statistic (2017)

Table II shows the population in Banten Province that are grouped based on the regency and city in Banten. Each regency and city always has an increase on its population year by year, so in other words, the populatuon in Tangerang is having a good potential for culinary business.

TABLE III. AVERAGE EXPENDITURE AND PERCENTAGE OF AVERAGE MONTHLY EXPENDITURE PER MONTH BY FOOD GROUP IN BANTEN PROVINCE

\begin{tabular}{ccc}
\hline Food Group & $\begin{array}{c}\text { Average } \\
\text { Expenditures } \\
\text { (IDR) }\end{array}$ & $\begin{array}{c}\text { Percentage of } \\
\text { Average Monthly } \\
\text { Expenditure }\end{array}$ \\
\hline Grains & 60.752 & 11,41 \\
Tubers & 3.878 & 0,73 \\
Fish/Shrimp/Squid/Shells & 32.340 & 6,07 \\
\hline
\end{tabular}

Table III shows the amount of average monthly expenditure per month by food group which is classified into 14 group. It can be seen that the consumption of egg and milk is $6,45 \%$ out of the total. It means that there's a demand on these product and people is looking for egg and milk.

Table IV shows the production of cacao beans in Indonesia from 2015 until 2017 that increased. It means that the demand of cacao beans that can be processed into chocolate product is increased. Based on the data of patisserie's ingredients, there are always a growth in the demand of the raw material used in patisserie products, and one of them is chocolate products.

Research of the potential chocolate products is important for the capital owner who is going to use the money for developing the culinary business. Through this research, the capital owner will have the information about the interest and demand of the chocolate product. This research is supported by the demand of the raw material related to the chocoalte product that sold in some cafe in Tangerang. 
TABLE IV. AVERAGE EXPENDITURE AND PERCENTAGE OF AVERAGE MONTHLY EXPENDITURE PER MONTH BY FOOD GROUP IN BANTEN PROVINCE (CONTINUED)

\begin{tabular}{ccc}
\hline Food Group & $\begin{array}{c}\text { Average } \\
\text { Expenditures } \\
\text { (IDR) }\end{array}$ & $\begin{array}{c}\text { Percentage of } \\
\text { Average Monthly } \\
\text { Expenditure }\end{array}$ \\
\hline Meat & 25.481 & 4,79 \\
Egg and Milk & 34.347 & 6,45 \\
Vegetables & 34.322 & 6,45 \\
Nuts & 11.040 & 2,07 \\
Fruits & 21.915 & 4,21 \\
Oil and Coconut & 11.849 & 2,23 \\
Beverage Ingredients & 15.599 & 2,93 \\
Spices & 9.660 & 1,81 \\
Other Consumption & 11.222 & 2,11 \\
Food and Beverage & 177.488 & 33,34 \\
Cigarette & 82.498 & 15,50 \\
\hline
\end{tabular}

Source: Indonesian Statistic (2017)

TABLE IV. INDONESIAN COCOA PRODUCTION (IN TON) AND BUSINESS STATUS

\begin{tabular}{cccc}
\hline \multirow{2}{*}{ Business Status } & \multicolumn{3}{c}{ Year } \\
\cline { 2 - 4 } & 2015 & 2016 & 2017 \\
\hline Smallholdings & 562.346 & 622.516 & 652.397 \\
State Plantations & 11.616 & 12.859 & 13.477 \\
Private Plantations & 19.369 & 21.442 & 22.471 \\
Total & 593.331 & 656.817 & 688.345 \\
\hline
\end{tabular}

Source: Tree Crop Estate Statistic of Indonesia (2017)

\section{LITERATURE REVIEW}

\section{A. Restaurant}

Restaurant is a commercial business that providing food and beverage for public (Becket, S.T., 2009). Restaurant is classified into some types (Statistic Indonesia, 17), there are:

1. Chain or Independent Restaurants

A Chain restaurant has some benefit, because the brand is known in the market, the range of advertising is wider, the system is advanced, and there's a discount in purchasing. While independent restaurant is easy to develop. The only thing needed is the starter capital, knowledge about the operational, and strong intention to reach the success. Example: Union Street Cafe.

2. Franchised Restaurants

Franchised restaurant is a good choice for the capital owner who is lack of experience in food service or restaurant, but has an intention to develop the outlet. Franchising is a good deal, because the risk of financial business is smaller, because ot the restaurant formaat, the design of the building, and the advertising planning is guaranteed in the market. More than that, the franchisor will providing the training, supporting the marketing activities, and giving some help in the management function. Example: KFC and Domino Pizza.

3. Hotel Restaurants

Hotel restaurant is a restaurant located inside the hotel and generally hire the professional chef with high fee. Restaurants in hotel are expected to increase the name of the hotel. Example: Spectrum, Fairmont Hotel Jakarta.

4. Fine-Dining Restaurants.

Fine dining leads to the food and service in the restaurant, where food and beverage can be enjoyed casually with expensive service from the restaurant through waiter/ess. The expensive fee should be balanced with the taste of the food, presentation, ambients, and experience offered by the restaurant. Example: GAIA by Oso Ristorante. 


\section{Coffee Shops}

At first, coffee shops is made with bar concept in Italia, which raises the culture of espresso that well known in Italia. These days, the concept has been developed, where coffee shops start to offer some variants of drinks and snack such as soup and sandwiches. Example: The Excelso.

\section{B. Dessert Restaurant}

The patisserie business has been developed at the baking techniques, form of products, decoration, delivery, and packaging that affect the restaurant business (Rangkuti, F.Y., and Wright, T., 2015). This development can be seen through the inovation of creating new variants of food and beverage. There are some types of desssert restarant, there are:

1. Bakery Café

First bakery café is established is America. Bkery café is a restaurant that offer bread, sandwich, and beverage as a complement (Statistic Indonesia, 2017). Example: Auntie Anne's.

2. Cafetaria atau café

Menurut Suas (2009: 885), Cafetaria atau café is a small restaurant that offer snacks such as cakes, sandwich, and non-alcoholic drinks such as tea and coffee [6]. Example: Cafe Oh Lala.

3. Chocolatier

Chocolatier is a place for the chocolate products being sold and professional who has an ability to produce chocolate products (Suas, 2009: 954). Example: Dapur Cokelat.

4. Patissiers

Menurut Suas (2009: 101), Patissiers is a French baking that sold french pastry products that already known since 15 century. Example: La Maison.

5. Chocolate

Chocolate is the variant of raw materials comes from the cocoa tree [6]. Chocolate has some different types, based on the city of origin manufature. However, all chocolates have two same characteristics (Sumarsono, dan Dicky, 2015), there are:

a. Taste. Even chocolate has some different flavors, but those flavors should be free from the flavors that disturbb the original taste of chocolate.

b. Texture. Chocolate should has a form texture at the room temperature between $20-25^{\circ} \mathrm{C}$ and melted smoothly in the mouth at $37^{\circ} \mathrm{C}$.

Cacao tree grows well between $20^{\circ}$ North and South Equatorial lines. There are three main area for the growing of cacao tree, those are South Africa, Southeast Asia, and North America, and the other seven country that produce chocolate with large production, such as Côte d'Ivoire, Ghana, Indonesia, Nigeria, Cameroon, Brazil, and Ecuador and the surrounding area [7]. Each country produces some variants of chocolate with different flavor.

There are four step on processing the cacao beans, those are harvest, fermentation, drying, storage and shipping. Furthermore, the final process of the cacao beans is make it into chocolate liquor, cocoa butter, and cocoa powder. Tere are five process for turning the cacao beans into the form of liquor, those are cleaning, roasting, winnowing, grinding and pressing chocolate liquor.

\section{METHODOLOGY}

\section{A. Data}

Data that support this research is collected from related sources. The potential of chocolate products is known by involving public on this research. Data is obtained from the result of questionnaire which is the method to getting the purpose of this research. Data about the demand of ingredients used in patisserie products or chocolate products collected from some related sources such as Indonesian Statistic and Tree Crop Estate Statistic of Indonesia (2018).

\section{B. Method}

Method used in this research is survey method by using the questionnaire. Data is collected through the result of respondent from the questionnaire, which is the instrument given to the respondent. Scale that used in each question is from number one until number six with description on each number. Number one for Strongly Disagree (SNA), number two for Disagree (NA), number 
three for Rather Disagree (RNA), number four for Rather Agree (RA), number five for Agree (A), and number six for Strongly Agree (SA).

After the questionnaire is collected from respondent, the next step need to be done is doing the reliability and validity test. Reliability test is testing the answer to each item in the intrument in order to be free from failure, and ensuring the accuracy for a fixed time, while validity test is a test used to measure how well an intrument is developed to measure a particular concept.

The questionnaire is divided into three parts. They are the respondent's profile, the market condition, and the products. The questions of the first part are: gender, age, salary per month, domicile, and profession of each respondent. Second part of the questionnaire is asking about the market condition. The questions are:

a. How many times in a month do you visit Tangerang area?

b. What is your main purpose every time you visit Tangerang? (Multiple answers is allowed)

c. How many times in a month do you visit the dessert café?

d. How much do you cost to buy a cake or dessert?

The third part of the questionnaire is discussing about the chocolate products sold in some dessert café. The questions are how reliable are you with the chocolate products such as:

a. Chocolate Praline (Chocolate products in a form of an attractive shape with an eye-catching colors on its shell, filled with chocolate gouache with some variant of flavors)

b. Chocolate Truffle (Chocolate products in a form of some shapes made with additional ingredients such as nuts and dried fruits).

c. Chocolate Dessert (Chocolate products made with chocolate and another ingredients such as dairy products, flour, sugar, fruits)

\section{IV.RESULT AND DISCUSSION}

\section{A. Result}

There are 252 respondents who take part on responding the questionnaire. The result of the questionnaire has been tested with reliability test and validity test. The result of reliability test is 0961 , which is greater than 0,70 and determined as a reliable result. The questionnaire is given to 252 respondents and come back with same number of amount and filled appropriate to the instruction given to each question. Therefore, all questionnaire is determined as a valid result for the research.

Table $\mathrm{V}$ shows the result from the first part of questionnaire. The question is about the demographic of respondent, that is gender, age, salary per month, domicile, and proffesion. From 252 respondents, it is found that 78 respondents are men (31\%) and 174 respondents are women (69\%), both men and women are having the interest on chocolate products. Age of respondents is grouped into five group. The dominant result is at age 20 to 30 years old with 175 respondents $(69 \%)$, and then age under 20 years old with 59 respondents (23\%), age $41-50$ years old with 9 respondents (4\%), age 31-40 years old with 5 respondents (2\%), and age above 50 years old with 4 respondents $(2 \%)$. Because of the dominant age at 20 to 30 years old, the salary per month of the respondents is dominated with the range salary between IDR 2.000.000 - IDR 5.000.000 with 206 respondents (82\%), and then salary per month more than IDR 5.000.000 - IDR 10.000 .000 with 21 repondents (8\%), salary per month more than IDR 10.000 .000 - IDR 15.000 .000 with 4 respondents (2\%), salary per month more than IDR 15.000.000 - IDR 20.000.000 with 3 respondent (1\%), and salary per month more than IDR 20.000 .000 with 12 respondents $(5 \%)$. The domicile of respondents is grouped into 6 area.

104 respondents $(41,30 \%)$ domiciled in Kabupaten Tangerang (Gading Serpong, Lippo Karawaci, Cikupa, dan Pasar Kemis), 103 respondents (40,87\%) domiciled in DKI Jakarta, 27 respondents $(10,71 \%)$ domiciled in Tangerang Selatan (Alam Sutera, BSD City, Pamulang, Villa Melati Mas, Serpong Utara, dan Graha Raya), 14 respondents $(5,55 \%)$ domiciled in Kota Tangerang (Tangerang,Ciledug, Green Lake City, Duta Garden, dan Rawa Bokor), 1 respondents $(0,40 \%)$ domiciled in Kabupaten Serang, and 3 respondents domiciled outside the listed area. Based on the dominant age of the respondents, the proffesion of the respondent is dominated with students with 213 respondents $(85 \%)$, then respondents with proffesions of employee with 21 respondents (8\%), 
entrepreneur with 7 respondents (3\%), housewife with 6 respondents (2\%), and other proffesions with 5 respondents $(2 \%)$.

TABLE V. DATA PROCESSED RESULT FOR THE FIRST PART OF THE QUESTIONNAIRE (DEMOGRAPHIC)

\begin{tabular}{|c|c|c|c|}
\hline \multirow{2}{*}{ Question } & \multicolumn{3}{|c|}{ Respondent } \\
\hline & Choice of Answer & Total & Percentage \\
\hline \multirow{3}{*}{ Gender } & Men & 78 & $31 \%$ \\
\hline & Women & 174 & $69 \%$ \\
\hline & Subtotal & 252 & $100 \%$ \\
\hline \multirow{6}{*}{ Age } & $<20$ years old & 59 & $23 \%$ \\
\hline & 20-30 years old & 175 & $69 \%$ \\
\hline & $31-40$ years old & 5 & $2 \%$ \\
\hline & $41-50$ years old & 9 & $4 \%$ \\
\hline & $>50$ years old & 4 & $2 \%$ \\
\hline & Subtotal & 252 & $100 \%$ \\
\hline \multirow{6}{*}{$\begin{array}{l}\text { Salary per } \\
\text { Month }\end{array}$} & $2.000 .000-5.000 .000$ & 206 & $82 \%$ \\
\hline & $>5.000 .000-10.000 .000$ & 21 & $8 \%$ \\
\hline & $>10.000 .000-15.000 .000$ & 4 & $2 \%$ \\
\hline & $>15.000 .000-20.000 .000$ & 3 & $1 \%$ \\
\hline & $>20.000 .000$ & 12 & $5 \%$ \\
\hline & Subtotal & 252 & $100 \%$ \\
\hline \multirow{7}{*}{ Location } & Kota Tangerang & 14 & $5,55 \%$ \\
\hline & Kabupaten Tangerang & 104 & $41,30 \%$ \\
\hline & Tangerang Selatan & 27 & $10,71 \%$ \\
\hline & Kabupaten Serang & 1 & $0,40 \%$ \\
\hline & DKI Jakarta & 103 & $40,87 \%$ \\
\hline & Others & 3 & $1,19 \%$ \\
\hline & Subtotal & 252 & $100 \%$ \\
\hline \multirow{6}{*}{ Occupation } & Student & 213 & $85 \%$ \\
\hline & Entrepreneur & 7 & $3 \%$ \\
\hline & Employees & 21 & $8 \%$ \\
\hline & Housewife & 6 & $2 \%$ \\
\hline & Other & 5 & $2 \%$ \\
\hline & Subtotal & 252 & $100 \%$ \\
\hline
\end{tabular}

Table 6 shows the result from the second part of the qustionnaire. Respondents respond the questions about market conditipns. Based on the results, market condition about the frequency of respondents visited Tangerang is grouped into 5 answers. Dominant respond is at 116 respondents (46\%) visited Tangerang for more than 8 times in a month, then 75 respondents (30\%) visited Tangerang for 1-2 times in a month, 37 respondents (15\%) visited Tangerang for 3-4 times a month, 17 respondents (7\%) visited Tangerang for 5-6 a month, and 7 respondents $(3 \%)$ visited Tangerang for 7-8 times a months. Based on the responds, it can be concluded that respondents has known well the Tangerang Area and Tangerang Area is a place that has been visited frequently. Main purpose of respondents visited Tangerang is grouped into 6 group and dominated with the purpose of going to 
mall with 147 respondents (35\%), then 127 respondents (30\%) are looking for lunch or dinner, 84 respondents (20\%) with the purpose of study (school/college), 23 respondents $(6 \%)$ for the purpose of work, 18 respondents (4\%) lived Tangerang, and 18 respondents (4\%) have another purpose outside the listed answers.

TABLE VI. DATA PROCESSED RESULT FOR THE SECOND PART OF THE QUESTIONNAIRE
(MARKET CONDITION)

\begin{tabular}{|c|c|c|c|}
\hline \multirow{2}{*}{ Question } & \multicolumn{3}{|c|}{ Respondent } \\
\hline & Choice of Answer & Total & Percentage \\
\hline \multirow{6}{*}{$\begin{array}{l}\text { How many times in a } \\
\text { month, you visit } \\
\text { Tangerang area? }\end{array}$} & $1-2$ times & 75 & $30 \%$ \\
\hline & $3-4$ times & 37 & $15 \%$ \\
\hline & $5-6$ times & 17 & $7 \%$ \\
\hline & 7 - 8 times & 7 & $3 \%$ \\
\hline & $>8$ times & 116 & $46 \%$ \\
\hline & Subtotal & 252 & $100 \%$ \\
\hline \multirow{6}{*}{$\begin{array}{l}\text { What is your main } \\
\text { purpose every time you } \\
\text { visit Tangerang? } \\
\text { (Multiple answers is } \\
\text { allowed) }\end{array}$} & Study (School/College) & 84 & $20 \%$ \\
\hline & Work & 23 & $6 \%$ \\
\hline & Lunch/Dinner & 127 & $30 \%$ \\
\hline & Going to Mall & 147 & $35 \%$ \\
\hline & Domiciled in Tangerang & 18 & $4 \%$ \\
\hline & Others & 18 & $4 \%$ \\
\hline \multirow{5}{*}{$\begin{array}{l}\text { How many times in a } \\
\text { month, you visit the } \\
\text { dessert café? }\end{array}$} & Subtotal & 252 & $100 \%$ \\
\hline & $1-3$ times & 205 & $81 \%$ \\
\hline & $4-6$ times & 24 & $10 \%$ \\
\hline & $7-9$ times & 4 & $2 \%$ \\
\hline & Others & 19 & $8 \%$ \\
\hline \multirow{6}{*}{$\begin{array}{l}\text { How much do you cost } \\
\text { to buy a cake or dessert? } \\
\text { (IDR) }\end{array}$} & Subtotal & 252 & $100 \%$ \\
\hline & $15.000-50.000$ & 124 & $49 \%$ \\
\hline & $>50.000-100.000$ & 99 & $39 \%$ \\
\hline & $>100.000-200.000$ & 23 & $9 \%$ \\
\hline & $>200.000-300.000$ & 5 & $2 \%$ \\
\hline & Subtotal & 252 & $100 \%$ \\
\hline
\end{tabular}

Source: Data Processed Result (2017)

Then the question is about the lifestyle of respondents around their interest of dessert cafe. There are 4 grouped answers. There are 205 respondents $(81 \%)$ visited dessert café for 1 to 3 time a month, 24 respondents (10\%) visited dessert café for 4 to 6 time a month, 4 respondents (2\%) visited dessert café for 7 to 9 time a month, and 19 respondents (8\%) are giving their own answer for this question. Based on the processed result, market condition about the money spent on every visit to dessert cafe is grouped into 4 groups. 124 respondents (49\%) spend IDR 15.000 - ID 50.000 on every visit, 99 respondents (39\%) spend more than IDR 50.000 - IDR 100.000 every visit and 23 respondents (9\%) spend more than IDR 100.000 - IDR 200.000 every visit and 5 respondents (2\%) spend more than IDR 200.000 IDR 300.000 every visit.

Table VII explains the interest of respondents with some of the chocolate products. Based on the result of the questionnaire, the respond about the chocolate product is good. 94 respondents $(37,3 \%)$ are agree with Chocolate Praline, that is a chocolate product in a form of an attractive shape with an eye-catching colors on its shell, filled with chocolate gouache with some variant of flavors, 103 respondents $(40,9 \%)$ are agree with Chocolate Truffle, that is a chocolate product in a form of some shapes, made with additional ingredients such as nuts and dried fruits, and 106 respondents $(42,1 \%)$ 
are strongly agree with the Chocolate Dessert, that is chocolates product made with chocolate and another ingredients such as dairy products, flour, sugar, and fruits.

\section{TABLE VII. DATA PROCESSED RESULT OF THIRD PART OF QUESTIONNAIRE (CHOCOLATE PRODUCT)}

\begin{tabular}{|c|c|c|c|}
\hline \multirow{2}{*}{ Question } & \multicolumn{3}{|c|}{ Respondent } \\
\hline & Choice of Answer & Total & Percentage \\
\hline \multirow{7}{*}{$\begin{array}{c}\text { Chocolate Praline } \\
\text { (Chocolate products in a } \\
\text { form of an attractive shape } \\
\text { with an eye-catching colors } \\
\text { on its shell, filled with } \\
\text { chocolate gouache with } \\
\text { some variant of flavors) }\end{array}$} & 1 (Strongly Disagree) & 1 & 0,4 \\
\hline & 2 (Disagree) & 11 & 4,4 \\
\hline & 3 (Rather Disagree) & 20 & 7,9 \\
\hline & 4 (Rather Agree) & 47 & 8,7 \\
\hline & 5 (Agree) & 94 & 37,3 \\
\hline & 6 (Strongly Agree) & 79 & 31,3 \\
\hline & Subtotal & 252 & 100 \\
\hline \multirow{7}{*}{$\begin{array}{c}\text { Chocolate Truffle } \\
\text { (Chocolate products in a } \\
\text { form of some shapes made } \\
\text { with additional ingredients } \\
\text { such as nuts and dried } \\
\text { fruits). }\end{array}$} & 1 (Strongly Disagree) & 1 & 0,4 \\
\hline & 2 (Disagree) & 4 & 1,6 \\
\hline & 3 (Rather Disagree) & 11 & 4,4 \\
\hline & 4 (Rather Agree) & 46 & 18,3 \\
\hline & 5 (Agree) & 103 & 40,9 \\
\hline & 6 (Strongly Agree) & 87 & 34,5 \\
\hline & Subtotal & 252 & 100 \\
\hline \multirow{7}{*}{$\begin{array}{l}\text { Chocolate Dessert } \\
\text { (Chocolate products made } \\
\text { with chocolate and another } \\
\text { ingredients such as dairy } \\
\text { products, flour, sugar, and } \\
\text { fruits) }\end{array}$} & 1 (Strongly Disagree) & 2 & 0,8 \\
\hline & 2 (Disagree) & 4 & 1,6 \\
\hline & 3 (Rather Disagree) & 9 & 3,6 \\
\hline & 4 (Rather Agree) & 35 & 13,9 \\
\hline & 5 (Agree) & 96 & 38,1 \\
\hline & 6 (Strongly Agree) & 106 & 42,1 \\
\hline & Subtotal & 252 & 100 \\
\hline
\end{tabular}

Source: Data Processed Result (2017)

\section{B. Discussion}

Based on the resulf of the questionnarire, the first part shows that both men and women are having an interest in chocolate products. The range age is dominated between 20 to 30 years old, with salary per month between IDR 2.000.000 to IDR 3.000.000. Mostly respondents are domiciled in Tangerang and DKI Jakarta. DKI Jakarta is one of the border areas of Tangerang, so people from DKI Jakarta are possible to go to Tangerang for some purpose. Related to the age of some respondents at 20 to 30 years old, the proffesion of the respondents are dominated with student and employee. Tangerang area is also an area that oftenly viited by people. Based on the questionnaire results part two, there are 116 respondents (46\%) who oftenly visited Tangerang for more than 8 times in a month. This means that Tangerang is a strategic area that can be used for capital owner to run a business in Tangerang. Most of the respondents visit Tangerang for the purpose of visiting mall and having a lunch or dinner in Tangerang. This kind of activties absolutely wil need the existence of restaurant in Tangerang are for people to having their meal while visiting mall through lunch or/and dinner. One of types of ther restaurant is dessert cafe. Another question appeared in the questionnaire is about the frequency of respondents visiting dessert cafe in a month. Mostly respondents are visiting dessert cafe for 1 to 3 times a month. It means that the existence of dessert cafe is still a matter for respondents. For every visit to dessert cafe, mostly respondents spend for IDR 15.000 to IDR 100.000 to purchase the 
products sold in the dessert cafe. The products on dessert cafe is responded well by the respondents because there are still an interest to purchase the products offer by the desseret cafe.

Product that offers on the dessert cafe is different from one dessert cafe to another. Chocolate products is one of the products sold in dessert cafe. Some of variants of chocolate products are Chocolate Praline, Chocolate Truffle, and Chocolate Dessert. Each products has a different characteristic and all of the products is responded well by the respondents. It means that chocolate products has a potential in dessert cafe. This statement also supported by the increasing number of demands for the chocolate products ingredients in Tangerang, and also the increasing plantation area of cacao tree that produce cacao beans which is going to be processed into main raw materials for chocolate products such as Chocolate Praline, Chocolate Truffle and Chocolate Dessert.

\section{V.CONCLUSION}

Tourism sector is giving a good impact for the local economy in the destination. One of the component on tourism sector is restaurant or also known as food services outlets. Patisserie has an important role in suppoting the success of restaurant and other food service business. The existence of patisserie is increasing, especially in Indonesia. Based on the processed questionnaire results, the respond of people with dessert cafe business or patisserie is good. People visited dessert cafe for at least once a month and spend some money to enjoy the products offer by the dessert cafe. One of the products that usually offer are the chocolate products.

Chocolate products that usually found in some dessert cafe are Chocolate Praline, Chocolate Truffle, and Chocolate Dessert. These three products are responded very well by the public. This statement is supported with the result of the questionnaire that refers to agree and strongly agree with these three products made with chocolate. Another supported data is come from the growth of demand for ingredients that are used for the chocolate products making. This research is measuring the interest of people with chocolate products that can be used as a measurement tools for capital owner who wants to run the dessert cafe business with chocolate products on the business. Based on the collected data and the collected questionnaires, chocolate products are having a good potential on affecting the existence of culinary business in Tangerang, Banten.

\section{REFERENCES}

Ana, Subekti, Sri and Hamidah, Siti. "The Patisserie Project Based Learning Model to Enhance Vocational Students' Generic Green Skills". In the Proceedings of UPI International Conference on Techincal and Vocational Education and Training (TVET), Atlantis Press (2015)

Beckett, Stephen T, "Industrial Chocolate Manufacture and Use," United Kingdom: Wiley-Blackwell, 2009.

Page, Stephen J, “Tourism Management $5^{\text {th }}$ Edition," London: Routledge, 2015.

Rangkuti, Fahwani Y. dan Wright, Thom (2015). Food Service Hotel Restaurant Institutional Update. GAIN Online. $\quad$ https://gain.fas.usda.gov/Recent\%20GAIN\%20Publications/Food\%20Service\%20\%20Hotel\%20Restaurant\%20Institutional_Jakarta_Indonesia_06-12-2017.pdf. Retrieved 26 January 2018.

Statistic Indonesia, https://www.bps.go.id/ Retrieved 31 July 2017.

Suas, Michael, "Advance Bread and Pastry," United States: Cengage Learning, Inc, 2009.

Sumarsono, Dicky, "Semua Orang Bisa Menjalankannya: Luar Biasa Bisnis Restoran di Indonesia," Jakarta: Gramedia Pustaka Utama, 2015.

Tree Crop Estate Statistic of Indonesia, http://ditjenbun.pertanian.go.id/ Retrieved 26 January 2018.

Walker, John R, “The Restaurant from Concept to Operation, $7^{\text {th }}$ ed," Hoboken: Wiley, 2014.

World Tourism Council, https://www.wttc.org/ Retrived 20 May 2017. 